\title{
Marketing Education and Computer Technology
}

\author{
Shwu-Huey Wang* \\ Department of Innovative Design and Entrepreneurship Management, Far East University, Taiwan
}

*Corresponding Author

Shwu-Huey Wang

\section{Article History}

Received: 15.08 .2020

Accepted: 22.08 .2020

Published: 29.08.2020

\begin{abstract}
Marketing is the subject that combines theory and practice in the business school. However, students were still provided with "speech and note-making" in a conventional classroom even in the modern highly competitive era. Though researchers have integrated computer technology with business education, it is regretful that students have limited opportunities to combine theory and practice in terms of marketing. The objective of the study is to explore the combination of marketing and marketing education. The study firstly explains the contents of marketing and the way to combine marketing education and the advanced computer technology. The study then employed modern advanced computer technology to build a simulated computer learning system, and the researcher randomly invited several college students to participate in the experiment. Finally, the preliminary results and conclusion are also provided.
\end{abstract}

Keywords: marketing education, computer technology, business education.

\section{INTRODUCTION}

Marketing is the subject that combines theory and practice in the business school. However, students were still provided with "speech and note-making" in a conventional classroom even in the modern highly competitive era. When the computer technology was intensively combined with marketing education, the business education became more advanced and to be more competitive. The goal of the present study is to address the efficiency of combining computer technology and marketing education. It is anticipated to bring new idea for business education and shorten the distance between theory and practice for the real world.

\section{Theoretical Context}

Marketing education and computer technology

Marketing education has been integrated with computer technology for many years. Moreover, computer technology is helpful on constructing students' marketing decision making ability through the design of a simulated situation; the following are a few examples: Lamont [1] developed team learning theory by integrating marketing theory with the interactive marketing simulation; students had to develop their marketing plan from class learning to practical application. The outcome was evaluated by the simulated system through the outputs such as market share, sales, profit, brand awareness and cash flow. He concluded that interactive simulation would play a revolutionary role in future marketing education. Ueltschy [2] integrated interactive multimedia technology into marketing curriculum. Students were requested to make marketing decisions like budget the promotion plan, pricing for the products, and deciding whether to distribute the products and input decision-related data into the system, then the system displayed the results in graphic forms for students to discuss and evaluate in the class. The results showed that the application of the interactive multimedia technology effectively increased student participation, understanding the material and lifted the course enjoyment in the process. Li, Greenberg, and Nicholls [3] introduced experiential learning to an MBA marketing curriculum, they requested students to establish a company in the virtual business world, students had to arrange the roles of executives, make strategic decisions and perform all the functions (examples like the arrangement of sales force, make decisions about segmentation and position of the products) in the way of a marketing professional. The findings demonstrated that students hold very positive opinions toward the innovative technology and regarded it as a viable alternative when compared with the usual lectured-based pedagogy.

Copyright @ 2020: This is an open-access article distributed under the terms of the Creative Commons Attribution license which permits unrestricted use, distribution, and reproduction in any medium for non commercial use (NonCommercial, or CC-BY-NC) provided the original author and source are credited. 
Computer technology can also enhance students' communicative ability through a virtual space: Molesworth [4] devised a virtual learning platform for students to have virtual seminars and explored the pedagogical value of the environment from the perspective of students; the platform provides a channel for students to interact and exchange opinions about the class. The findings indicated that students' opinions toward the system are mixed but concluded that it is beneficial on learning overall.

Students' ability to analyze and understand customer's preference can also be achieved through the help of computer technology: Miller, Holmes, and Mangold [5] applied the technique of geographic information system (GIS) to marketing curriculum, a brief case situation related to marketing was presented in the process, and students were requested to analyze the customized datasets that concerned with their market and competitors by utilizing the tools. The results indicated that students generally consented that the GIS is beneficial to their learning.

Based on the cases described above, the trend of utilizing interactive technology in marketing education seems not to be reversed. Though there is much multimedia instructional facilitation available for Marketing learning, the computer technology designed in the study seems to be more effective for it is visualized, interactive and quite different from the ways that have been used in the previous works. Harper, Hedberg and Wright [6] pointed that besides reality, virtual environments may be the most suitable method to create an authentic environment based on the needs of learners. Therefore, we may infer that the computer technology that employed in the present study would be a helpful and appropriate way on marketing learning in the future.

However, all of the cases stated above are limited within computer-simulated activities.

\section{Marketing mix}

McCarthy [7] presented the concepts of Product, Price, Place and Promotion (4Ps) to be the four key factors to make decisions in marketing. As the concepts are terse and easy to remember, they have become the most often-used classification method of marketing mix both in fields of theory and practice [8].

The first P, Product, refers to the policies and procedures that related to the product varieties such as qualities, product designs, features, brand name or product sizes to be offered. As it is essential for companies to develop competitive products to acquire market share, marketers should have acute sense on evaluating product's advantages and disadvantages from different dimensions. For instance, a product with a brand name that is easy to remember may gain customers' preference; while the second P, Price, talks about the pricing policies in different situations and setting various pricing strategies based on corporate objectives. To be capable and effective in pricing strategy, a marketer has to visualize the whole market's competitive situation. The following provides an example, if the competitor adopts low pricing strategy, marketer has to evaluate whether to choose the same decision based on the resources of the company; Place strategy means the channel design that connects the targeted customer and plant and the decision making of location choice. To make a correct distribution decision, marketers have to be able to assess if the channel is suitable according to the product's characters so the limited resources will not be wasted. Daily goods is a notable example, for this kind of product is classified as consuming goods, they need to be distributed intensively so that consumers can get it everywhere; the $4^{\text {th }} \mathrm{P}$, Promotion, combines the concepts of communication and psychology and explores the effects of sales promotion, and advertising $[9,10]$. Marketers need to be capable to communicate with the customers to effectively perform the designed marketing plan, meanwhile, a well-designed promotion campaign may increase market share but cost a lot, so marketers need to make the most feasible plan according to the firm's disposable resources.

Consequently, the contents of marketing combine's theory and practice and how to enable students to apply the class knowledge to the real life is the learning essence of the subject.

Table-1: Components of marketing mix

\begin{tabular}{|l|l|l|l|}
\hline \multicolumn{4}{|c|}{ Marketing mix } \\
\hline Product & Price & Place & Promotion \\
\hline Product variety & List price & Channels & Sales promotion \\
\hline Quality & Discounts & Coverage & Advertising \\
\hline Design & Allowances & Assortments & Sales force \\
\hline Features & Payment period & Locations & Public relations \\
\hline Brand name & Credit terms & Inventory & Direct marketing \\
\hline Packaging & & Transport & \\
\hline Sizes & & & \\
\hline Services & & & \\
\hline Warranties & & & \\
\hline Returns & & & \\
\hline
\end{tabular}

Source: Adapted from Kotler et al. [10]. Marketing management: An Asian perspective, 4th Ed., Prentice Hall, New York. 


\section{METHOD}

The study randomly invited several college students, whose background are all business, to participate in the pilot study. They were provided with a short orientation to understand the entire procedure of the experiment. The learning environment was build up by a scenario-based computer technology; the participants had to fix the vivid-like problems in the environment. Then the solutions proposed by the participants were recorded in the system to be graded by the graders.

\section{Results ANd CONCLUSION}

The preliminary results showed quite favorable results, which indicated that applying computer technology to marketing education would be beneficial to increase student learning performance and shorten their adaptation from theory to practice. In the experiment, the participants all revealed that combining computer technology to marketing learning is not only interesting but also helpful in learning. It is anticipated that there would be more and more cases to apply computer technology to business education in the future, and hopefully the learning outcome would be improved more easily.

\section{REFERENCES}

1. Lamont, L. M. (2001). Enhancing student and team learning with interactive marketing simulations. Marketing Education Review, 11(1), 45-55.

2. Ueltschy, L. C. (2001). An exploratory study of integrating interactive technology into the marketing curriculum. Journal of Marketing Education, 23(1), 63-72.

3. Li, T., Greenberg, B. A., \& Nicholls, J. A. F. (2007). Teaching experiential learning: Adoption of an innovative course in an MBA marketing curriculum, Journal of Marketing Education, 29(1), 25-33.

4. Molesworth, M. (2004). Collaboration, reflection and selective neglect: campus-based marketing students' experiences of using a virtual learning environment. Innovatons in Education and Teaching International, 41(1), 7992.

5. Miller, F. L., Holmes, T. L., \& Mangold, W. G. (2007). Integrating Geographic Information Systems (GIS) into the marketing curriculum. Marketing Education Review, 17(3), 49-63.

6. Harper, H., Hedberg, J., \& Wright, R. (2000). Who benefits from virtuality? Computers \& Education, 34, $163-176$.

7. McCarthy, E. J. (1960). Basic Marketing, Homewood, IL: Richard D. Irwin.

8. Van Waterschoot, W., \& Van den Bulte, C. (1992). The 4P classification of the marketing mix revisited. Journal of marketing, 56(4), 83-93.

9. Borden, N. (1964). The concept of the marketing mix. Journal of Advertising Research, 4, 2-1.

10. Kotler, P., Keller, K. L., Ang, S. H., Leong, S.M., \& Tan, C. T. (2006). Marketing management: An Asian perspective, $4^{\text {th }}$ ed., Prentice Hall, New York. 